\title{
Parenteral Vial
}

National Cancer Institute

\section{Source}

National Cancer Institute. Parenteral Vial. NCI Thesaurus. Code C43226.

A container designed for use with parenteral drug products. 